\title{
Darier's Disease - A Case Report
}

\author{
S. Srikanth ${ }^{1 *}$, J. Rajitha ${ }^{2}$
}

${ }^{1}$ Professor, Department of Pathology, Malla Reddy Institute of Medical Sciences, Hyderabad, Telangana, India

${ }^{2}$ Associate Professor, Department of Pathology, Chalmeda Anand Rao Institute of Medical Sciences, Karimnagar, Telangana, India

DOI: $10.36347 /$ sjmcr.2021.v09i03.023

| Received: 28.02.2021 | Accepted: 17.03.2021 | Published: 22.03.2021

*Corresponding author: Dr. S. Srikanth

Abstract

Darier's disease or keratosis follicularis is a rare autosomal dominant genodermatosis, which is characterized by greasy, crusted, keratotic, yellow brown warty papules and plaques particularly over seborrhoeic areas. Darier disease is a skin condition characterized by wart-like blemishes on the body. The blemishes are usually yellowish in color, hard to the touch, mildly greasy, and can emit a strong odor. The most common sites for blemishes are the scalp, forehead, upper arms, chest, back, knees, elbows, and behind the ear. Although this is a genetically transmitted disease according to a larger series, about $47 \%$ of patients had no clear family history, presumably because of incomplete penetrance. The prevalence of this disorder in population is $1: 100,000$. The sex incidence is equal, although the males appear to be more severely affected than females. The oral mucosa is affected in $50 \%$ of the cases, and lesions are usually asymptomatic and discovered during routine dental examination. Lesions are represented by multiple firm papules with normal, whitish, or reddish color, primarily affecting the palatal and alveolar mucosa.

Keywords: Darier's, autosomaol dominant, corps, ronds.

Copyright $\odot 2021$ The Author(s): This is an open-access article distributed under the terms of the Creative Commons Attribution 4.0 International License (CC BY-NC 4.0) which permits unrestricted use, distribution, and reproduction in any medium for non-commercial use provided the original author and source are credited.

\section{INTRODUCTION}

Darier's disease, also known as keratosis follicularis, dyskeratosis follicularis, or Darier-White disease, is a relatively rare autosomal dominant skin disorder with abnormal keratinization and loss of epithelial adhesion. Its prevalence in the population ranges from $1: 30,000$ to $1: 100,000$, with no gender difference [1, 2]. Although this condition is a dominant genetic inheritance, the report of sporadic cases is approximately $40-50 \%$, presumably of new mutation or incomplete penetrance. The characteristic feature of this disease is the presence of multiple, skin-colored to yellow-brown, hyperkeratotic papules predominantly in seborrheic areas, such as the face and upper trunk.

The symptoms and signs of Darier disease vary markedly between individuals. Some have very subtle signs that are asymptomatic and found only on careful inspection. Others have extensive lesions which can cause considerable distress to the affected individual. In an affected person the severity of the disease can fluctuate over time.

The skin lesions are characterised by persistent, greasy, scaly papules. Affected sites include:
Seborrhoeic areas of the face (scalp margins, forehead, ears, around the nostrils and sides of nose, eyebrows, and beard area), Scalp and neck, Central chest and back, Skin folds, such as armpits, groin, under the breasts, and between the buttocks.

The papules have a firm, harsh feel like coarse sandpaper and may be skin-coloured, yellow-brown, or brown in colour. If several of the small papules grow together they may form larger warty lesions which can become quite smelly within skin folds. There may be a heavily crusted rash similar to seborrhoeic dermatitis.

Other skin signs may include: Small pits on the palms and soles and Bleeding under the skin. Atypical presentations of Darier disease are common. Flat, freckle-like lesions, Blistered papules, Large, raised, warty lesions and A linear pattern, with papules following the lines of embryonal development of the skin (segmental distribution).

\section{Case Report}

A 32 years male patient came to Dermatology out patient department with multiple pruritic papules on the upper chest since puberty. The patient also complained of pruritus and odor of the lesions, which 
was aggravated by sunlight and sweating. No specific family history was given. Physical examination revealed multiple skin-colored hyperkeratotic papules coalescing into plaques. Biopsy was done and sent for histopathological examination. On gross the biopsy was aroung $4 \mathrm{~mm}$ in diameter and it was submitted totally. On microscopy there were multiple discrete zones of suprabasal clefts with acanthosis, dyskeratotic cells in the stratum spinosum and stratum granulosum described as "corps ronds," and parakeratotic cells in the stratum corneum which resemble "corps grains" or focal acanthotic dyskeratosis (Figure-1).

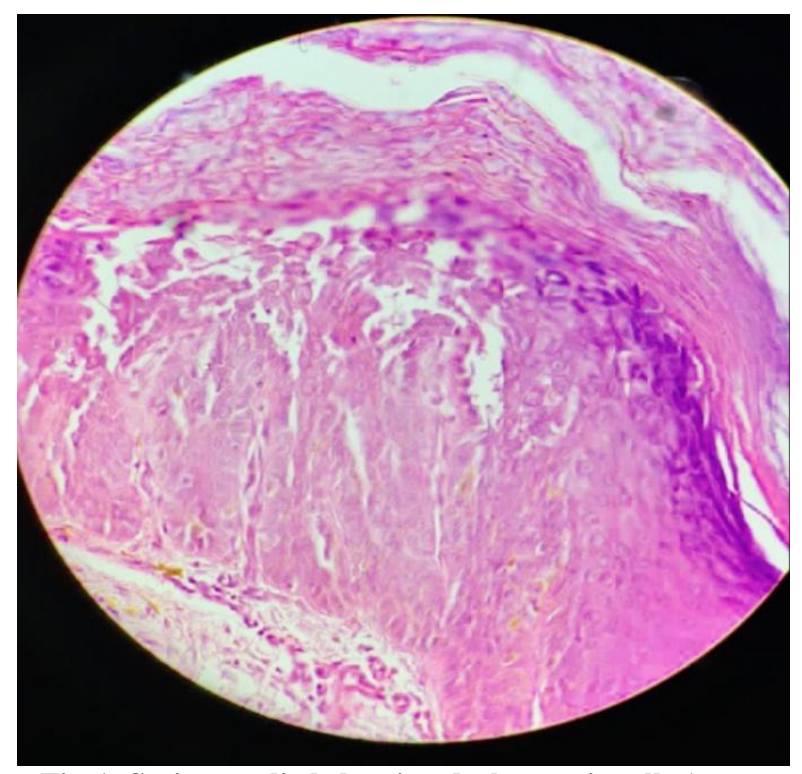

Fig-1: Secion studied showing dyskeratotic cells (corps ronds and grains) reflecting acantholysis and premature keratinization (400x, H\&E) - Suggestive of Darier's disease

\section{DISCUSSION}

Darier's disease was first described by Prince Marrow in 1886 and later independently described by Darier and White in 1889. The condition is a genodermatosis with an autosomal dominant inheritance caused by a mutation in the ATP2A 2 gene, at chromosome 12q23-12q24.

The characteristic feature of Darier's disease includes the presence of multiple, skin-colored to yellow-brown, hyperkeratotic papules distributed in seborrheic areas, such as the head, neck, and trunk. Other clinical findings include flexural vegetative lesions, wart-like papules on the dorsal side of the hands and feet, palmoplantar pits, red and white longitudinal bands and distal wedge shape of the nail plate, and cobblestone papules on the oral mucosa $[3$, 4].
In addition to classic manifestations, longstanding facial lesions may later develop skin thickening with ridges and furrows on the face compatible with leonine facies. The development of leonine facies could be explained by the long duration of untreated disease, leading to multiple confluent hyperkeratotic papules and plaques on the face, forming ridges and furrows.

Histologically, Darier's disease is characterized by acantholysis which forms suprabasal clefts and also formation of "corps rond and grains" superficially. Corps ronds are usually present in the granular cell layer and show central large round dyskeratotic basophilic masses surrounded by a clear halolike zone.

Darier's disease must be distinguished histologically from other acantholytic dyskeratoses, such as Haily-Haily disease (familial benign pemphigus) and Grover's disease (transient acantholytic dermatosis). In Haily-Haily disease, acantholysis is incomplete, causing the well-known "dilapidated brick wall" appearance of the lower epidermis. The clinical characteristics of these diseases are different from those of Darier's disease.

Biopsy is necessary to arrive at definitive diagnosis. Patients should be referred for dermatological examination and should be informed about the possible complications like bad odors, caries, and secondary infections. Psychiatric opinion should follow in more severe cases. Therefore, it is important to ensure multidisciplinary approach in the management of patients with Darier's disease.

\section{REFERENCES}

1. Tavadia S, Mortimer E, Munro CS. Genetic epidemiology of Darier's disease: a population study in the west of Scotland. Br J Dermatol. 2002 Jan;146(1):107-9.

2. Suryawanshi H, Dhobley A, Sharma A, Kumar P. Darier disease: a rare genodermatosis. J Oral Maxillofac Pathol. 2017 May-Aug;21(2):321.

3. Bernabé DG, Kawata LT, Beneti IM, Crivelini MM, Biasoli ER. Multiple white papules in the palate: oral manifestation of Darier's disease. Clinical and Experimental Dermatology. 2009 Oct 1:e270-1.

4. Sakuntabhai A, Ruiz-Perez V, Carter S, Jacobsen $\mathrm{N}$, Burge S, Monk S, Smith M, Munro CS, O'Donovan M, Craddock N, Kucherlapati R. Mutations in ATP2A2, encoding a Ca 2+ pump, cause Darier disease. Nature genetics. 1999 Mar;21(3):271-7. 